\title{
GSK-3 $\beta$ is essential for physiological electric field-directed Golgi polarization and optimal electrotaxis
}

\author{
Lin Cao $\cdot$ Jin Pu $\cdot$ Min Zhao
}

Received: 16 May 2010/Revised: 3 December 2010/Accepted: 7 December 2010/Published online: 5 January 2011

(C) The Author(s) 2010. This article is published with open access at Springerlink.com

\begin{abstract}
Endogenous electrical fields (EFs) at corneal and skin wounds send a powerful signal that directs cell migration during wound healing. This signal therefore may serve as a fundamental regulator directing cell polarization and migration. Very little is known of the intracellular and molecular mechanisms that mediate EF-induced cell polarization and migration. Here, we report that Chinese hamster ovary $(\mathrm{CHO})$ cells show robust directional polarization and migration in a physiological EF $(0.3-1 \mathrm{~V} / \mathrm{cm})$ in both dissociated cell culture and monolayer culture. An EF of 0.6 $\mathrm{V} / \mathrm{cm}$ completely abolished cell migration into wounds in monolayer culture. An EF of higher strength $(\geq 1 \mathrm{~V} / \mathrm{cm})$ is an overriding guidance cue for cell migration. Application of EF induced quick phosphorylation of glycogen synthase kinase $3 \beta$ (GSK- $3 \beta$ ) which reached a peak as early as $3 \mathrm{~min}$
\end{abstract}

L. Cao and J. Pu contributed equally to this work.

L. Cao $\cdot$ M. Zhao

Department of Dermatology, University of California, Davis,

CA 95618, USA

M. Zhao

Department of Ophthalmology, University of California, Davis, CA 95618, USA

L. Cao $\cdot$ M. Zhao

Institute for Regenerative Cures, University of California, Davis, CA 95618, USA

L. Cao $\cdot$ J. Pu $(\bowtie) \cdot$ M. Zhao

School of Medical Sciences, University of Aberdeen, IMS Building, Foresterhill, Aberdeen AB25 2ZD, Scotland, UK

e-mail: jin.pu@abdn.ac.uk

M. Zhao $(\bowtie)$

University of California, 2921 Stockton Blvd, Sacramento, CA 95817, USA

e-mail: minzhao@ucdavis.edu in an EF. Inhibition of protein kinase C (PKC) significantly reduced EF-induced directedness of cell migration initially (in 1-2 h). Inhibition of GSK-3 $\beta$ completely abolished EF-induced GA polarization and significantly inhibited the directional cell migration, but at a later time $(2-3 \mathrm{~h}$ in an $\mathrm{EF})$. Those results suggest that GSK- $3 \beta$ is essential for physiological EF-induced Golgi apparatus (GA) polarization and optimal electrotactic cell migration.

Keywords Physiological electric field . Cell polarization · Golgi polarization . Directional cell migration · Wound healing
Abbreviations
$\mathrm{EF}(\mathrm{s}) \quad$ Electric field(s)
DC Direct current
GA Golgi apparatus
PI3K Phosphatidylinositol 3 kinases
GSK-3 $\beta \quad$ Glycogen synthase kinase- $3 \beta$

\section{Introduction}

It has long been proposed that electric fields (EFs) at the site of wounds may serve as a signal directing cells to migrate into the wounds [1-6]. Endogenous EFs were detected hundreds of years ago and have been confirmed in several laboratories with modern techniques [7-10]. At skin and corneal wounds in animals and in humans, several different techniques including micro-electrodes, microneedle arrays, and EF-imagers measured the naturally occurring EFs about $0.42-1.7 \mathrm{~V} / \mathrm{cm}$ in the superficial layers and at the surface of wounds [11, 12-14]. The field strength in the tissues, however, is likely to be smaller, 
because of lower resistance in the tissues underneath the superficial epithelial layers and exponential decrease due to volume conductance of the deeper tissues. A reasonable estimation is a voltage value of about $40 \mathrm{mV} / \mathrm{mm}$ within the epidermis [14]. Most published data have used higher voltages and provided significant insights into cellular and molecular mechanisms of EF-induced biological effects. A key question remains as to how the applied EFs used are related the physiological EFs.

Applied EFs induce cell polarization and directional cell migration $[2,3,9,10,15-18]$. We demonstrated that EFs of physiological strength are an overriding guidance cue that directs cell migration during wound healing of corneal epithelial wounds [19-21]. This signal therefore may serve as a fundamental regulator directing cell polarization and migration [7, 19, 20, 22, 23]. Very little is known of the molecular mechanisms that mediate EF-induced cell polarization and migration.

Golgi apparatus (GA) is important in cell polarization and directional cell migration [24]. In response to directional cues in wounds, cells extend membrane protrusion, elongate, and form a leading edge towards the direction of cues-the wound center [25-29]. Efficient migration requires coordination in many cellular activities, such as directed secretion to provide new membrane components to the leading edge [30,31]. Primary polarization cues initiated at the cell's leading edge are relayed to the GA complex, triggering a second set of signaling events that controls the subsequent remodeling of the secretary pathway [32]. Recent evidence suggests that the GA, in addition to its function in protein secretion, may be the site of signaling events important for diverse cellular processes [33-35]. GA-localized signaling pathway is required both for the clustering of the GA around the microtubule organizing center (MTOC) and for its polarization in migrating cells [36]. Disruption of GA by brefeldin A (BFA) inhibited lamellopodia activity and significantly affected cell polarization [16, 37]. When cells in culture migrate to close a scratch wound, this directional extension is accompanied by GA reorientation, to face the leading wound edge, giving the motile cell inherent polarity aligned to the direction of cell migration at the wound edge [25, 26, 29, 38, 39].

Glycogen synthase kinase-3 (GSK-3) was originally identified as one of several protein kinases capable of phosphorylating the rate-limiting enzyme of glycogen deposition, GS (glycogen synthase) [40]. Significantly, GSK is also a central molecule mediating cell polarization $[25,26]$. Wounding results in a small GTPase Cdc42dependent inhibition of GSK-3 through phosphorylation on Serine 9, this correlates with its dissociation from cell polarity molecule Par6. Inhibition of either $\mathrm{Cdc} 42$ or protein kinase $\mathrm{C}$ (PKC), or expression of a constitutively active version of GSK-3, blocks reorientation of the
MTOC. Cdc42, Par6-PKC, and phosphorylated GSK-3 all orientated into the leading edge, where a polarizing signal should be active. Blocking GSK-3 or PKC, however, does not abolish the formation of membrane protrusions. Instead, they become randomly orientated, suggesting an overlap with other polarization mechanisms [41].

We previously reported that a strong EF of $3.0 \mathrm{~V} / \mathrm{cm}$ induces pronounced GA polarization towards the cathode [16]. In this study, we aimed to answer the question whether physiological EFs induce directional GA polarization and cell migration. We found this to be the case. We further investigated the role of GSK-3 $\beta$ and PKC in GA polarization and electrotaxis.

\section{Materials and methods}

Chemical agents and cell cultures

Cell culture media and reagents were purchased from Invitrogen (USA). Human fibronectin was from SigmaAldrich (USA). GF109203X (inhibitor of PKC), SB216763 (GSK-3 inhibitor), Ly294002 and Wortmannin (PI3-kanase inhibitors) were purchased from EMD Chemical (USA). GSK-3 $\beta$ inhibitor XII and GSK-3 inhibitor XVI were purchased from CALBIOCHEM (USA). CHO cells were purchased from ATCC (USA) and grown in NM-F12 medium, with $5 \%$ fetal bovine serum (FBS), $50 \mathrm{U} / \mathrm{mL}$ penicillin, and $50 \mu \mathrm{g} / \mathrm{mL}$ streptomycin. $\mathrm{CO}_{2}$-independent medium was used for experiments performed in room atmosphere. CHO cells were starved for $3 \mathrm{~h}$ in serum-free NM-F12 medium before wounding or treatment with inhibitors. For wound-healing assays, $\mathrm{CHO}$ cells were plated on the electrotactic chamber (as described previously [42]) and allowed to grow to confluence before wounding. A monolayer was manually wounded with a 10- $\mu$ l tip. Wounded CHO monolayer were subject to an EF for $3 \mathrm{~h}$ and subsequently used for immunofluorescence analysis. All experiments were performed within passage five of $\mathrm{CHO}$ cells and triplicates.

\section{EF stimulation}

CHO cells were seeded at low density in electrotactic chambers on fibronectin-coated $\left(10 \mu \mathrm{g} / \mathrm{cm}^{2}\right)$ Falcon tissue culture dishes for 16-20 h, allowing them to settle and adhere to the base of the dish, before EF exposure. A roof consisting of a No. 1 coverglass was applied and sealed with high vacuum silicone grease (Dow Corning Corporation, USA) on top of the chamber as described previously [42]. The final dimensions of the chamber, through which the electric current was passed, were $40 \mathrm{~mm} \times 10 \mathrm{~mm} \times$ $0.3 \mathrm{~mm}$. The different strengths of DC EFs were supplied 
through agar-salt bridges connecting silver/silver chloride electrodes via beakers of Steinberg's solution to pools of culture medium at either side of the chamber. This prevents diffusion of electrode products into the cultures. The dish was placed under a Zeiss Axiovert 100 (Germany) microscope with a stage incubator controlling temperature at $37^{\circ} \mathrm{C}$.

\section{Analysis of GA polarization}

For the GA staining, CHO cells were subjected to different strengths of EFs for $3 \mathrm{~h}$, then fixed in $4 \%$ paraformaldehyde $(15 \mathrm{~min})$, permeabilized $(5 \mathrm{~min}$ in $0.2 \%$ Triton $\mathrm{X}-100$ ) and blocked for $30 \mathrm{~min}$ with blocking solution

Fig. 1 EFs of physiological strength directed GA polarization in $\mathrm{CHO}$ cells. a-f Fluorescent images showed GA (red) in CHO cells cultured in the absence (a) or presence of an EF for $3 \mathrm{~h}$. The cells were fixed and triple-labeled with GM130 antibody (GA marker, red), FITC-phalloidin (F-actin, green), and DAPI (blue). g GA polarization was quantified as the percentage of GA polarized into the quadrant between 45 and 315 degrees in the field direction as shown. $\mathbf{h}$ An EF of $0.3 \mathrm{~V} / \mathrm{cm}$ induced significant GA polarization, which was more pronounced with increased field strength. $* P<0.01$ compared to no EFs control. Scale bar $20 \mu \mathrm{m}$ a

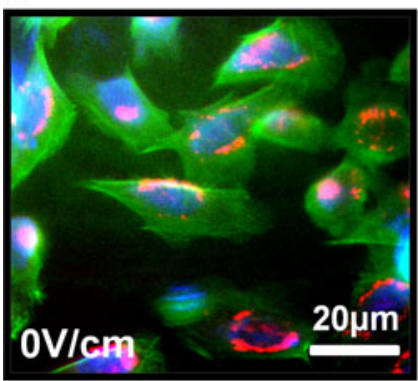

d

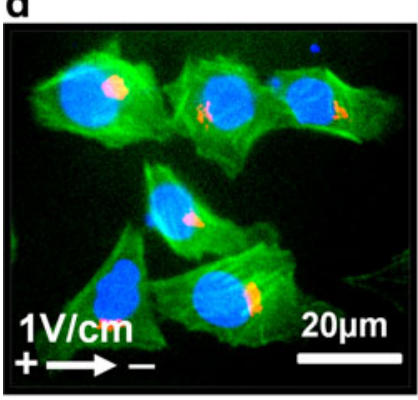

g
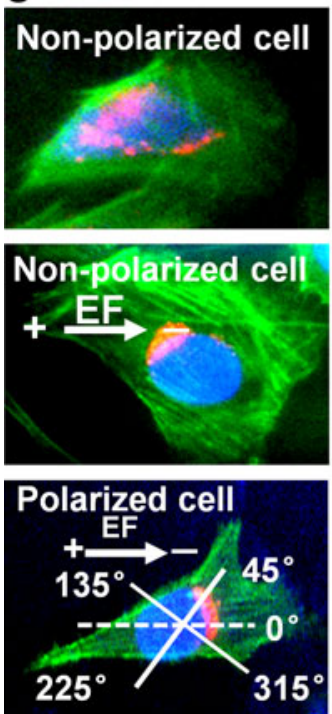

(10\% goat serum, $1 \% \mathrm{BSA}$ and $0.02 \% \mathrm{NaN}_{3}$ in PBS). A monoclonal antibody against GM130 (1:100; BD, Franklin Lakes, USA) was used to label the GA $(1 \mathrm{~h}$ at room temperature). After washing, the cells were incubated with Texas Red conjugated secondary antibodies (1:200; Jackson Immuno-Research Laboratories, USA) and phalloidin-FITC (1:100; Sigma-Aldrich, USA) for $1 \mathrm{~h}$ at room temperature. Nuclei were stained with DAPI. Images were obtained under $\times 40$ fluor oil immersion lens of a Zeiss inverted fluorescence microscope (Zeiss Axiovert 100, Germany) with MetaMorph software. Cells in which the GA was within the quadrant facing to between 45 and $315^{\circ}$ of the EF direction were scored as polarized in the $\mathrm{EF}$ direction (Fig. 1g) [16]. Cells with no EF supplied were b

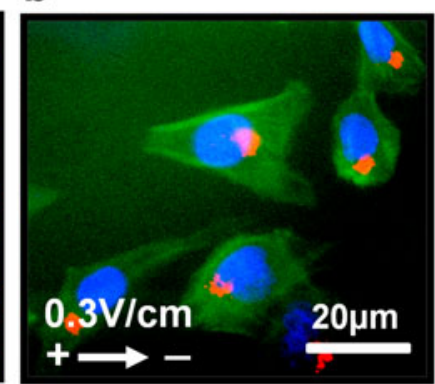

e

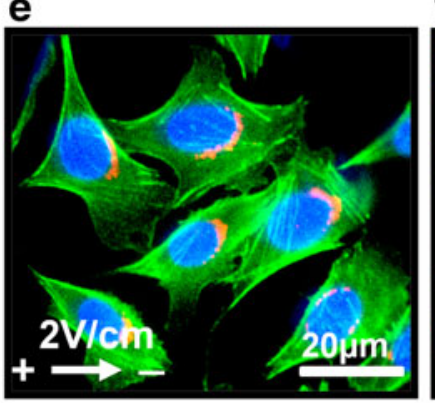

C
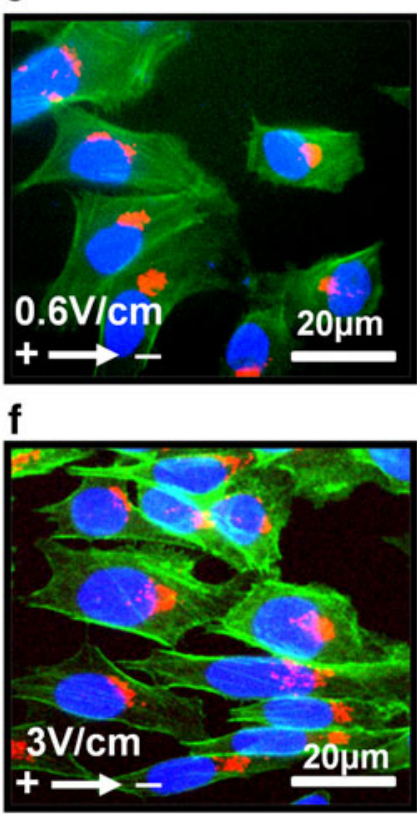

\section{h Golgi polarization}

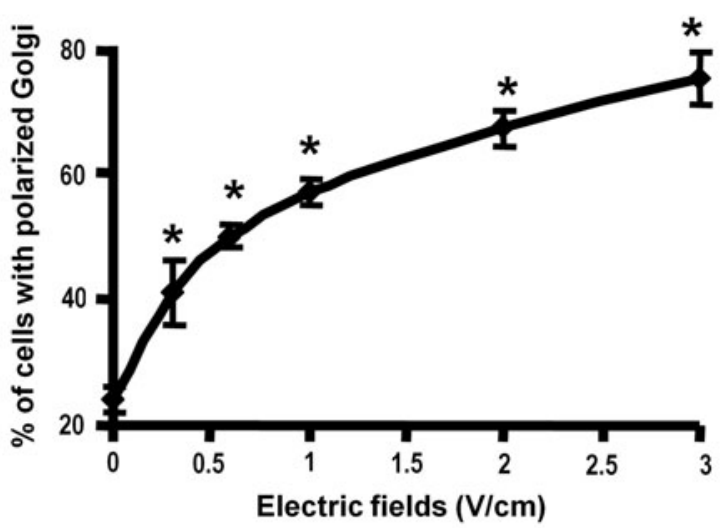


regarded as control. The percentage of polarized cells \pm SEM was calculated from three separate experiments.

\section{Western blot analysis}

Cells were starved in serum-free culture medium overnight before to be applied to $2.0 \mathrm{~V} / \mathrm{cm}$ EF in vitro. Protein levels of phosphorylated GSK- $3 \beta$, total GSK- $3 \beta$ and phosphorylated Akt were determined at different time points after EF treatment. For inhibitor experiments, cells were preincubated with $20 \mu \mathrm{M}$ GF109203X, $20 \mu \mathrm{M}$ SB216763, $1 \mu \mathrm{M}$ GSK-3 $\beta$ inhibitor XII, $1 \mu \mathrm{M}$ GSK-3 inhibitor XVI, $30 \mu \mathrm{M}$ Ly294002, and $200 \mathrm{nM}$ Wortmannin, respectively, for $1 \mathrm{~h}$ and then were applied to $\mathrm{EF}$ for $5 \mathrm{~min}$ to display the phosphorylated GSK-3 or $3 \mathrm{~h}$ for detection of catenin. After various treatments, $\mathrm{CHO}$ cells were rinsed with cold PBS and lysed with lysis buffer $(10 \mathrm{mM}$ Tris-HCL, $50 \mathrm{mM}$ $\mathrm{NaCl}, 5 \mathrm{mM}$ EDTA, $50 \mathrm{mM}$ sodium fluoride, $1 \%$ Triton $\mathrm{X}-100,30 \mathrm{mM} \mathrm{Na}_{4} \mathrm{P}_{2} \mathrm{O}_{7}, 1 \mathrm{mM}$ sodium orthovanadate and protease inhibitor cocktail; Boehringer-Ingelheim, Germany). Equal amounts of protein lysates were resolved by $4-12 \%$ SDS-PAGE, followed by electroblot analysis onto nitrocellulose membrane (Invitrogen, USA). The membranes were stained with Ponceau $\mathrm{S}$ for detection of transfer efficiency, then were blocked with 5\% milk TBS (pH 7.4 with $0.1 \%(w / v)$ Tween 20) for $1 \mathrm{~h}$. Incubate membrane with relevant primary antibodies respectively (1:1000, Anti-phospho-Akt, anti- $\beta$-catenin, anti-phosphoGSK- $3 \beta$ and total GSK- $3 \beta$ from Cell Signaling, USA, and anti- $\alpha$-tubulin from Sigma-Aldrich) overnight at $4^{\circ} \mathrm{C}$. Antirabbit/mouse secondary antibody with horseradish peroxidase (1:4,000; Sigma-Aldrich) was used, and the immunoblots were detected by an enhanced chemiluminescence (ECL) detection system (Amersham Pharmacia Biotech, UK).

Time-lapse imaging system and quantification of cell migration

Time-lapse images were recorded every $5 \mathrm{~min}$ and analyzed with a MetaMorph system (MDS Analytical Technologies, USA) [43]. Migration directedness (cosine $\theta$ ) shows how directionally a cell migrated within the field, where $\theta$ is the angle between the EF vector and a straight line connecting the start and end position of a cell [42]. A cell moving perfectly toward the cathode would have a directedness of 1; a cell moving perfectly along the field lines toward the anode would have a directedness of -1 . Therefore, the average of directedness values of a population of cells gives an objective quantification of how directionally the cells have moved. A group of cells migrating randomly would have an average directedness value of 0 . Migration rate was analyzed with the following three parameters. Trajectory speed $(T t / T)$ is the total length of the migration trajectory of a cell (Tt) divided by the given period of time $(T)$. Displacement speed $(T d / T)$ is the straight-line distance between the start and end positions of a cell $(T d)$ divided by the time $(T)$. Displacement speed along the $x$-axis $(D x / T)$ is a cell's displacement distance along the $x$-axis $(D x)$ divided by the time $(T)$.

Cross flow experiment

To exclude the possibility that GA polarization might be an indirect effect mediated by chemical or ionic gradients, temperature, or $\mathrm{pH}$ variation, we conducted a more stringent control using a cross-current medium flow chamber modified from that described by Erickson and Nuccitelli [44, 45]. In this experimental setup, the electrotactic chamber was perfused constantly with the culture medium in a direction perpendicular the EF vector. A continuous flow of copious culture medium through the electrotactic chamber was maintained with a peristaltic pump during the entire experimental period $\left(24 \mathrm{~mL} / \mathrm{h}\right.$, through a $0.2-\mathrm{mm}^{2}$ channel). This eliminated possible build up of chemoattractant or ionic gradients and maintained stable temperature and $\mathrm{pH}$ across the chamber during experiments.

\section{Results}

Physiological EFs direct GA polarization

In cells not exposed to an EF, the GA was positioned randomly relative to the nucleus (Fig. 1a). In an EF of $0.3 \mathrm{~V} / \mathrm{cm}$, the GA polarization toward the cathode increased significantly from 24 to $41 \%(P<0.01)$ (Fig. 1 b, h). The percentage of GA polarized towards the cathode increased gradually when $\mathrm{CHO}$ cells were subjected to higher field strengths (Fig. 1b-f, h).

Physiological EFs direct cell migration

In the absence of an applied EF, CHO cells migrated in random directions. The cells have an average net cosine of $0.08 \pm 0.06$ (directedness) (Fig. 2a). When cultured in a physiological EF as low as $0.3 \mathrm{~V} / \mathrm{cm}, \mathrm{CHO}$ cells showed evident directional migration toward the cathode with a directedness of 0.3 ( $P<0.01$ compared to no EF control) (Fig. 2b). Cells extended lamellipodia in the direction of migration within 10-15 min after the onset of the EF. Electric stimulation increased the number of cells moving toward the cathode. Exposure to an EF of $0.6 \mathrm{~V} / \mathrm{cm}$ for $3 \mathrm{~h}$ resulted in $91 \%$ of the cells moving toward the right quadrant (Fig. 2c). The directedness of $\mathrm{CHO}$ cells migrating to the cathode peaked at $3.0 \mathrm{~V} / \mathrm{cm}(0.91 \pm 0.02)$. CHO cells respond to EFs with a threshold at or less than $0.3 \mathrm{~V} / \mathrm{cm}$ (Fig. 2f). 
Exposure to EFs of physiological strength significantly increased the trajectory and translocation speed of cells (Fig. $2 \mathrm{~g}$ ). At $0.6 \mathrm{~V} / \mathrm{cm}$, the migration speed is twice and displacement speed is 2.5 -fold of the value in control cells $(P<0.01)$. The fastest speed of cell migration is $\sim 20.8 \mu \mathrm{m} / \mathrm{h}$ for trajectory speed $(T t / T)$ and $16.7 \mu \mathrm{m} / \mathrm{h}$ for displacement speed $(T d / T)$ following application of the EF of $2.0 \mathrm{~V} / \mathrm{cm}$. The increases the migration speed showed a clear voltage dependency (Fig. $2 \mathrm{~g}$ ). The migration speeds reached a plateau EF at $2.0 \mathrm{~V} / \mathrm{cm}$ and above.

Physiological EF directs GA polarization at the monolayer wound edges

Scratch wounding on a monolayer induces robust polarization of the cells towards the wound, as revealed by the reorientation of the $\mathrm{GA}$ in the direction of the movement in many cell types. We observed GA polarization of the wound-edge cells at $3 \mathrm{~h}$ after wounding with or without EF exposure. Directional cues such as mechanical stimulation, wound void, and chemical gradients are present in this model. Cells exhibited a polarized GA towards the wound in $\mathrm{CHO}$ cells at the wound edge (Fig. 3a). GA polarization at the first line of wound edge cells is $70 \pm 2.6 \%$, but just one-half of cells at the second and third line showed GA polarity toward the wound (second line $37 \pm 4.2 \%$, third line $39 \pm 4.3 \%$, data not shown). When an EF of $1.0 \mathrm{~V} / \mathrm{cm}$ was applied with the field vector in the normal healing direction, GA polarized more directionally towards the wound ( $85 \pm 3.9 \%, P<0.05$; Fig. 3b, e). Moreover, $\mathrm{CHO}$ cells showed obvious GA polarity not only at the first line of wound edges but also at the second and third line of cells (69 \pm 11.9 and $54 \pm 9.9 \%$, respectively; $P<0.001$, data not shown) compared to no field control. An additional
Fig. 2 EFs of physiological strength directed migration of $\mathrm{CHO}$ cells. a-e The migration trajectories of $\mathrm{CHO}$ cells for a period of $3 \mathrm{~h}$ in absence or presence of an EF showed significant directional migration in an $\mathrm{EF}$ of $0.3 \mathrm{~V} / \mathrm{cm}$ or higher voltage. Each cell's position at $0 \mathrm{~h}$ is positioned at the origin $(0,0)$. $\mathbf{f}$ Voltage dependence of migration directedness of $\mathrm{CHO}$ cells showed a threshold below $0.5 \mathrm{~V} / \mathrm{cm}$. g Trajectory speed and displacement speed along the $x$-axis all increased with the field strength of the applied EFs. All results were from three independent experiments. ${ }^{*} P<0.01$ compared to no field control. Directedness and migration speed values are shown as mean \pm SEM, with total number of cells as $n$ a $\operatorname{Cos} \theta=0.08 \pm 0.06(n=55)$
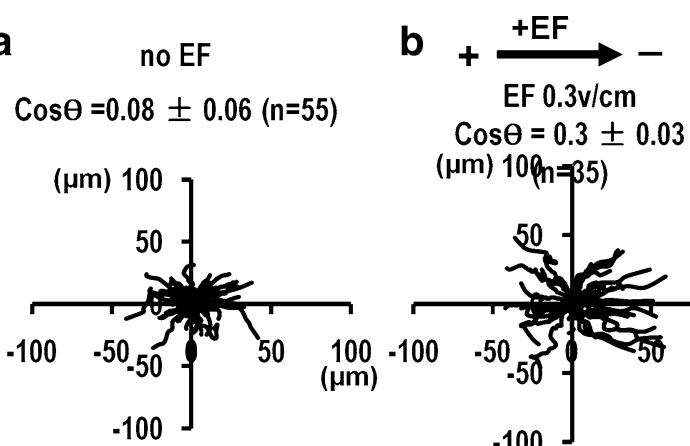
$\left.(\mu \mathrm{m}) 10 \rho_{n=35}\right)$

d

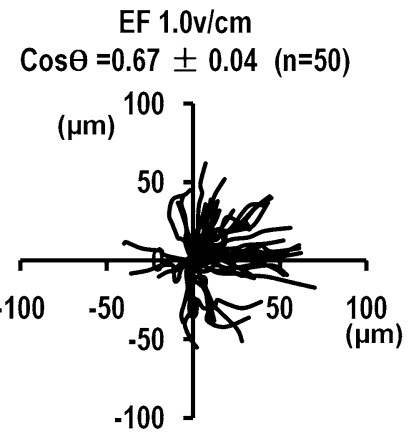

f

Voltage dependent migration directedness

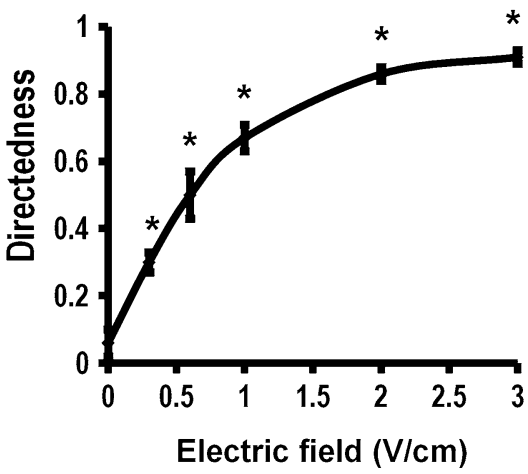

C

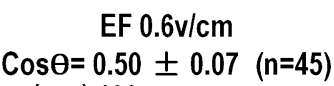
( $\mu \mathrm{m}) 100$

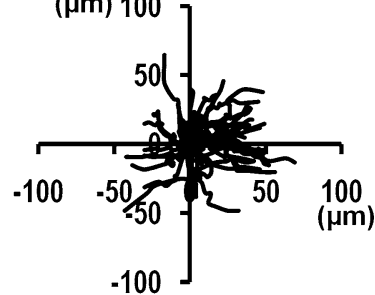

$-100$
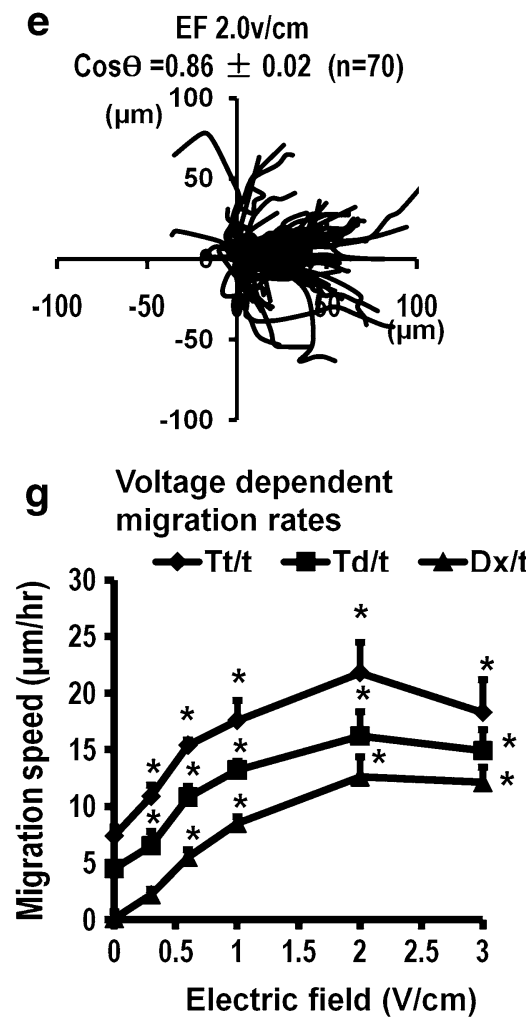
increase of EF strength to 2.0 and $3.0 \mathrm{~V} / \mathrm{cm}$ did not further increase GA polarization $(P>0.05$ compared to $1.0 \mathrm{~V} / \mathrm{cm}$; Fig. 3c-e). When an EF of $1.0 \mathrm{~V} / \mathrm{cm}$ was applied opposite to the normal healing direction, GA still polarized toward the wound healing direction (Fig. 3f, g). When the field increased to 2.0 and $3.0 \mathrm{~V} / \mathrm{cm}$, GA polarized away from the wound toward the cathode (Fig. 3h, i, j).

EF-directed GA polarization in monolayer wound edge and local chemical gradients

In our experimental system, the mechanical cues were present throughout. Were the chemical gradients formed at
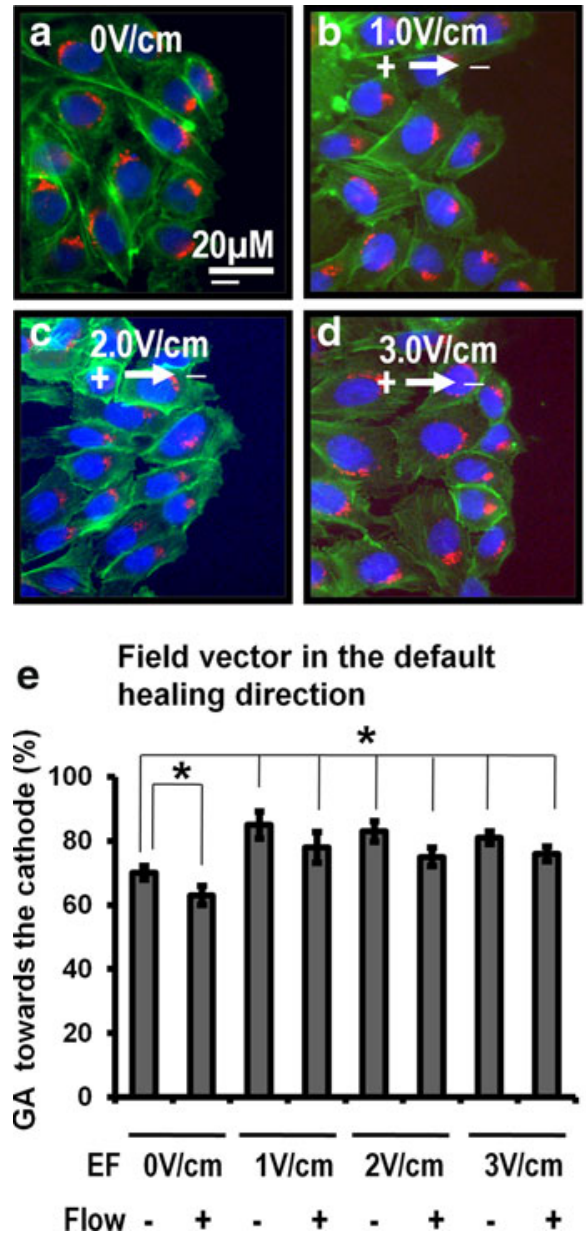

Fig. 3 A physiological EF directed GA polarization in the scratch wound model. a-d An EF applied in the default healing direction significantly increased GA polarization into the wound. e GA polarization in the first rows of cells at wound edge was shown. EFs of $1.0,2.0$ and $3.0 \mathrm{~V} / \mathrm{cm}$ in the default healing direction significantly increased GA polarization into the wound to the same extent. GA polarization at $1.0,2.0$ and $3.0 \mathrm{~V} / \mathrm{cm}$ was reduced by a continuous medium flow perpendicular to the EF lines with no significant difference. f-i An EF applied against the default healing direction polarized the GA away from the wound. $\mathbf{j}$ GA polarization in the first row at EF against wound edge with/without medium flow the wound affected by the applied EF? Is GA polarization in a wounded monolayer mainly due to the direct effects of the applied EF, or indirectly by chemical gradients caused by the applied EFs? To exclude possible chemotaxis effects, we did experiments by maintaining continuous flow of culture medium perpendicular to EF lines at different field strength $1.0,2.0$ and $3.0 \mathrm{~V} / \mathrm{cm}$. The continuous medium flow indeed had significant effects on the GA polarization either when the EF polarity was in the healing direction or against the default healing direction, especially at higher field strength (Fig. 3e, j). But for most experiments, the EF-induced GA polarization remained. These results suggest that the chemical gradients also play an
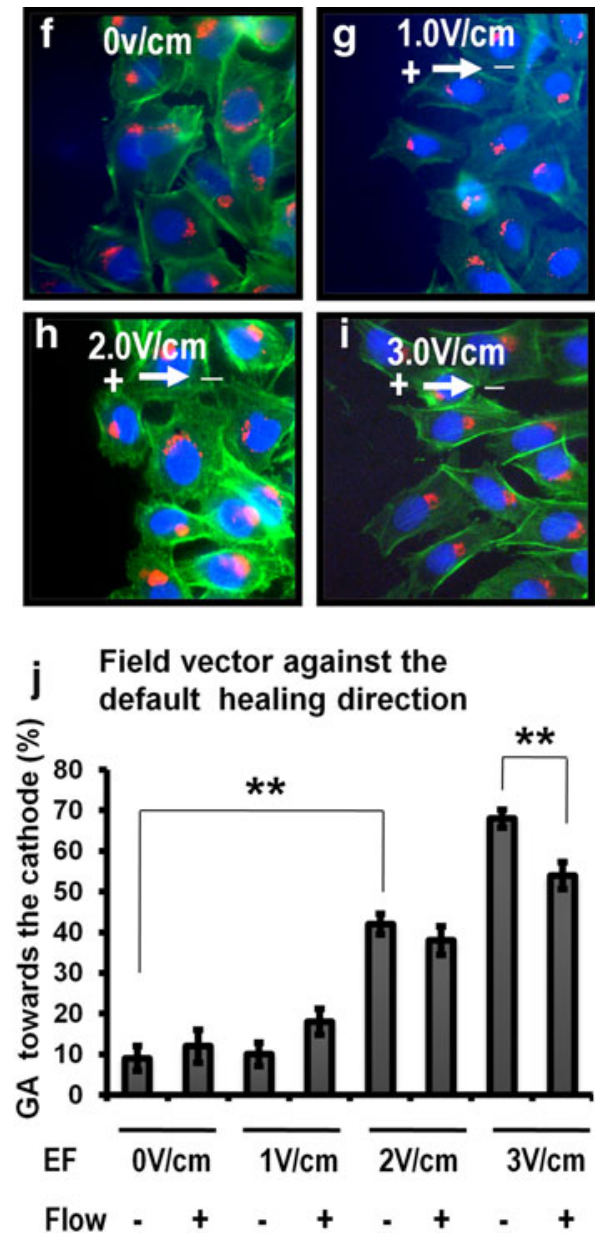

was shown. GA polarization at $3.0 \mathrm{~V} / \mathrm{cm}$ was significantly reduced in medium flow. The medium flow was maintained during the experiments to exclude possible chemotaxis. The flow of copious culture medium through the electrotactic chamber was maintained with a peristaltic pump during the entire experimental period $(24 \mathrm{~mL} / \mathrm{h}$, through $0.2 \mathrm{~mm}^{2}$ channel). Data were grouped from three independent experiments. The percentage of cells with GA polarized in the $\mathrm{EF}$ direction is shown as mean \pm SEM. Monolayer culture of $\mathrm{CHO}$ cells were wounded and allowed to heal for $3 \mathrm{~h}(\mathbf{a}-\mathbf{i})$. The cells were triple-labeled with actin (green), GM130 (red), and DAPI (blue). $* P<0.05,{ }^{*} * P<0.01$ when compared to control. Bar $20 \mu \mathrm{m}$ 
important role in the EF-induced GA polarization in this wounded monolayer model.

Physiological EF is a predominant cue directing cell migration at monolayer wounds

We analyzed the polarity and motility of the cells at the edge of a scratch wound made on the $\mathrm{CHO}$ cell monolayer. In a control condition without applied EFs, wounding induced migration of the remaining intact cell sheet into the gap (Fig. 4a, b). When a small EF of $0.3 \mathrm{~V} / \mathrm{cm}$ was applied with a polarity requiring cells to migrate anodally to heal a wound, $40 \%$ of cells did not move into the wound and instead moved toward the cathode. The directedness changed from -0.74 (wound without EF) to -0.37 (Fig. 4c). When the field strength was increased to $0.6 \mathrm{~V} / \mathrm{cm}, 56 \%$ of cells moved to the cathode with a directedness of 0.02 (Fig. 4d). The mean distance moving into the wound was $0.94 \pm 2.7 \mu \mathrm{m} / \mathrm{h}$ $(10.8 \pm 0.2 \mu \mathrm{m} / \mathrm{h}$ for no field control). This result indicated that an EF of $0.6 \mathrm{~V} / \mathrm{cm}$ (anode facing the default healing direction) stopped wound healing completely. With EFs larger than $0.6 \mathrm{~V} / \mathrm{cm}$, cell migration simply followed the direction of an applied EF and ignored all other cues generated by wounding a monolayer of $\mathrm{CHO}$ cells (Fig. 4e, f). We also analyzed the overriding effect on wound monolayer, which we found to be voltage dependent (Fig. 4g).
Fig. 4 A physiological EF was a predominant cue directing cell migration in monolayer wound healing. a Cells at one side of the wound edges migrated to the left. The following experiments were done on this side of the wound. b Migration trajectories of cells at the wound in the absence of an EF were shown. c-f An EF was applied with the field vector against the normal healing direction. Each cell's position at $t=0$ is positioned at the origin. Trajectories of cell migration were shown for a period $3 \mathrm{~h}$ in the EF. Migration of the cells into the wound was significantly reduced at $0.3 \mathrm{~V} /$ $\mathrm{cm}$, and was stopped at $0.6 \mathrm{~V} /$ $\mathrm{cm}$. The migration direction was completely reversed and cells migrated away from the wound in an EF of 1 and $2 \mathrm{~V} / \mathrm{cm}$. g Directedness of cell migration was voltage dependent with a threshold less than $1 \mathrm{~V} / \mathrm{cm}$. $\operatorname{Cos} \theta$ is mean values of directedness \pm SEM. $n$ the total number of cells at the given condition a
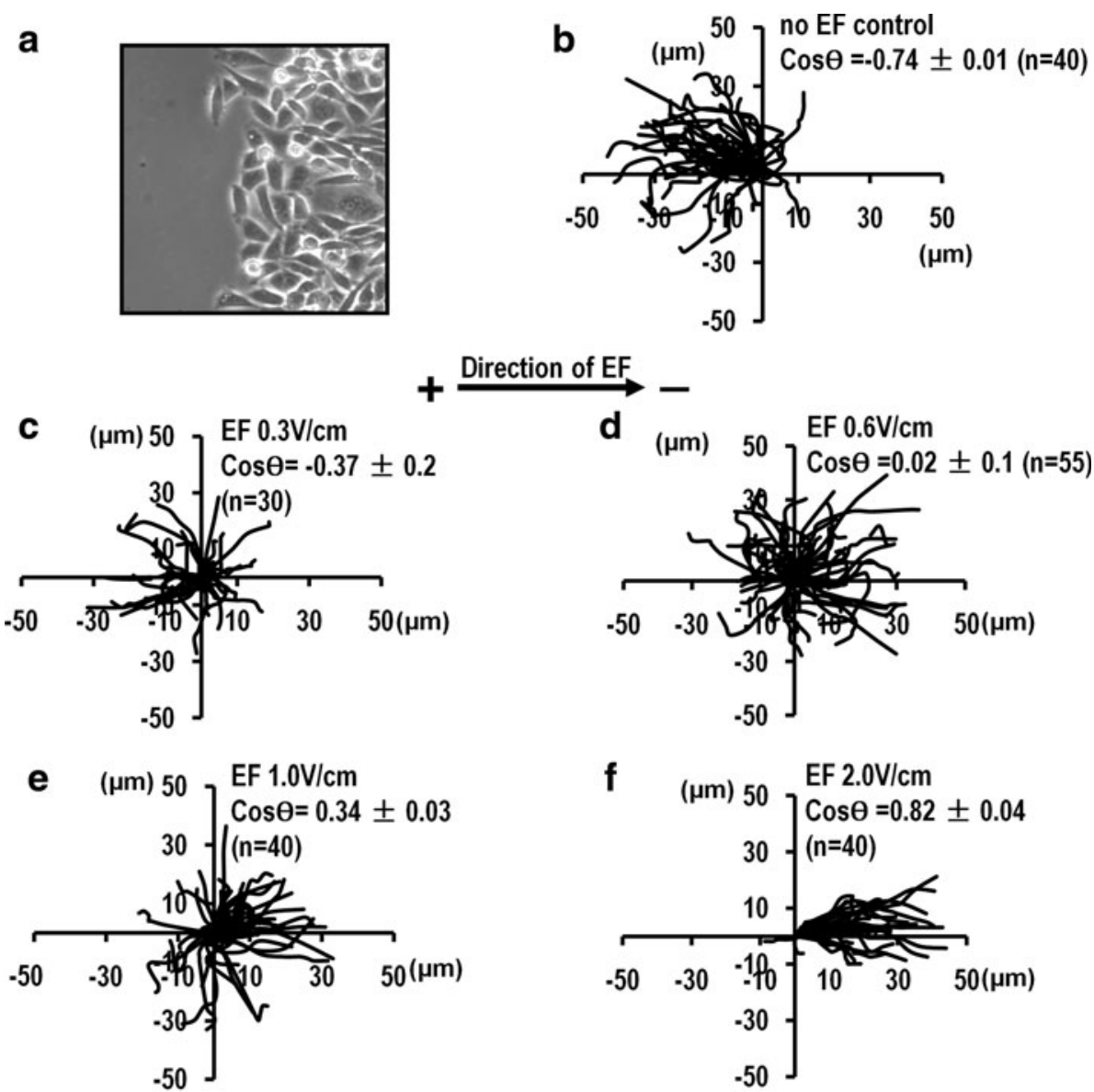

Field vector against

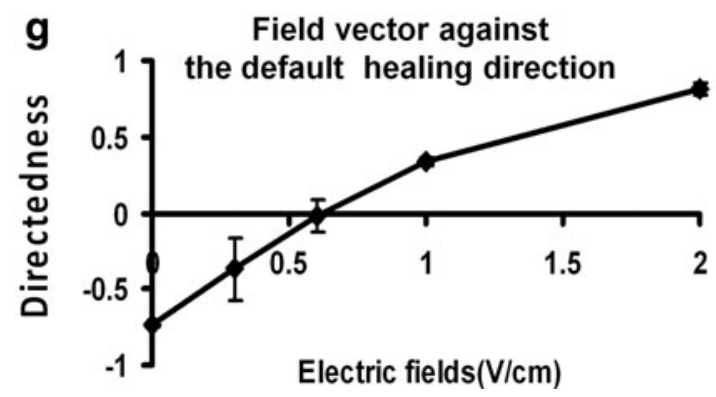

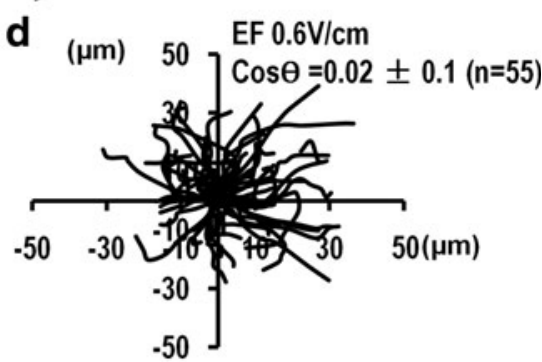

f $(\mu \mathrm{m}) 50 \mathrm{EF} 2.0 \mathrm{~V} / \mathrm{cm}$

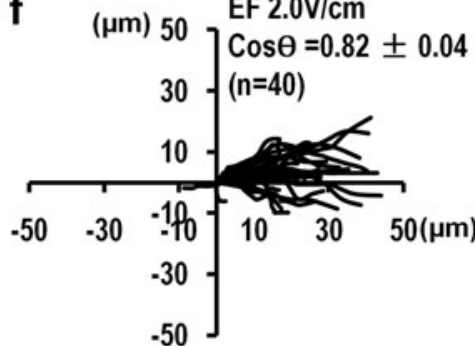


EFs induced phosphorylation of Akt, GSK-3 $\beta$ and down-regulation of $\beta$-catenin

To identify signaling elements involved in EF-directed GA polarization, we examined the phosphorylation state of GSK-3 $\beta$ and total GSK-3 $\beta$, a critical protein in the establishment of cell polarity [26, 46, 47]. The level of phosphorylation at serine 9 of GSK-3 $\beta$ reaches a maximum level at $3 \mathrm{~min}$ after $\mathrm{EF}$ application and then gradually decreases to the basal level at $1 \mathrm{~h}$ (Fig. 5b). This is one of the earliest molecules we found to be activated by an applied EF. The phosphorylation level of Akt also reached a peak $3 \mathrm{~min}$ after exposure to an EF, which persists for $1 \mathrm{~h}$ (Fig. 5a). The total GSK-3 $\beta$ and Akt did not change at EF-stimulated samples (Fig. 5a, b, lower channels). When PI3K were inhibited by $30 \mu \mathrm{M}$ Ly294002 and $200 \mathrm{nM}$ Wortmannin, the phosphorylation of GSK-3 $\beta$ was significantly reduced (Fig. 5e). It indicates that the EF can induce the phosphorylation of GSK-3 $\beta$ mediated by PI3K/Akt. In addition, we found that the level of $\beta$-catenin as a marker for function of GSK-3 is reduced by EF application (Fig. 5f). Inhibition of GSK-3/GSK-3 $\beta$ (1 $\mu \mathrm{M}$ GSK-3 inhibitor XVI or $1 \mu \mathrm{M}$ GSK-3 $\beta$ inhibitor XII) can significant increased the level of $\beta$-catenin (Fig. 5f). This result suggests that EF can affected the function of total GSK-3 $\beta$ protein.

Inhibition of PKC abolished phosphorylation of GSK-3 $\beta$

Atypical protein kinase (PKC) is required to establish and control cell polarity [26, 47]. To test whether GSK-3 $\beta$ phosphorylation induced by an EF is dependent on PKC signaling, cells were pretreated with PKC inhibitor GF109203X (GF) prior to EF application. Inhibition of PKC completely prevented GSK-3 $\beta$ phosphorylation
Fig. 5 An EF induced the phosphorylation of GSK-3 $\beta$. a, b (upper channels) Time courses of phosphorylation of Akt and GSK-3 $\beta$ were analyzed with western blotting. a, b (lower channels) The expression of total GSK-3 $\beta$ and Akt were no different between the EF-supplied and no EF control. c GF109203X (GF, PKC inhibitor) completely inhibited the phosphorylation of GSK-3 $\beta$. d SB216763 (SB, inhibitor of GSK-3 $\beta$ ) did not inhibit the phosphorylation of GSK-3 $\beta$. e Phosphorylation of GSK- $3 \beta$ could be inhibited by inhibitors of PI3K $(30 \mu \mathrm{M}$ Ly294002 and $200 \mathrm{nM}$

Wortmannin) and inhibitor of PKC (20 $\mu$ M GF109203X). GF109203X (GF, PKC inhibitor) completely inhibited the phosphorylation of GSK- $3 \beta$. f $\beta$-catenin as a marker of GSK-3 function was downregulated by EF. Inhibition of GSK-3 with $1 \mu \mathrm{M}$ GSK-3 inhibitor XVI (GSK-3in XVI) or GSK- $3 \beta$ with $1 \mu \mathrm{M}$ GSK- $3 \beta$ inhibitor XII (GSK-3 $\beta$ in XII) could increase the expression of $\beta$-catenin. $\alpha$-Tubulin or GAPDH was used as protein loading control. Histograms show the relative intensity of phosphoGSK $3 \beta$ and phospho-Akt over the tubulin control.

$E F=2.0 \mathrm{~V} / \mathrm{cm}$. All results were from three independent experiments a
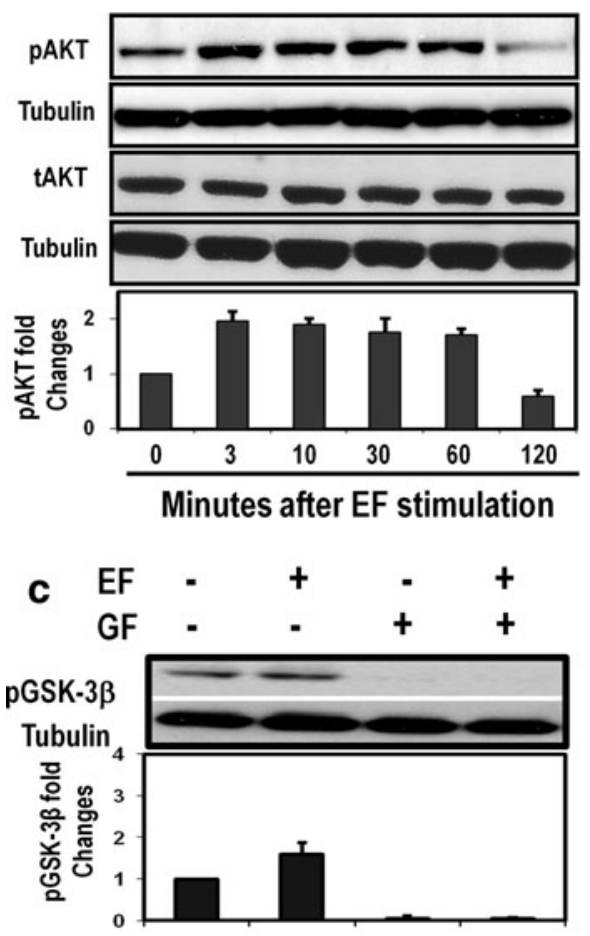

e

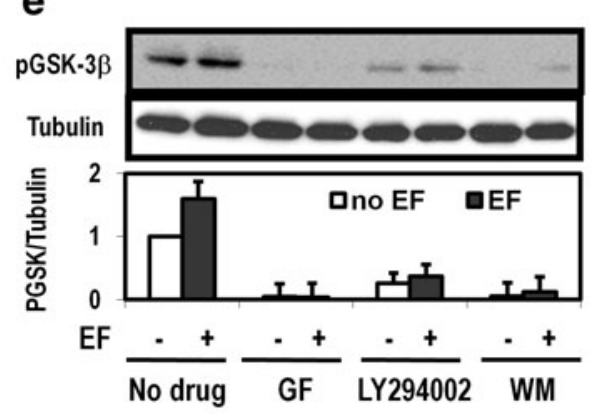

b
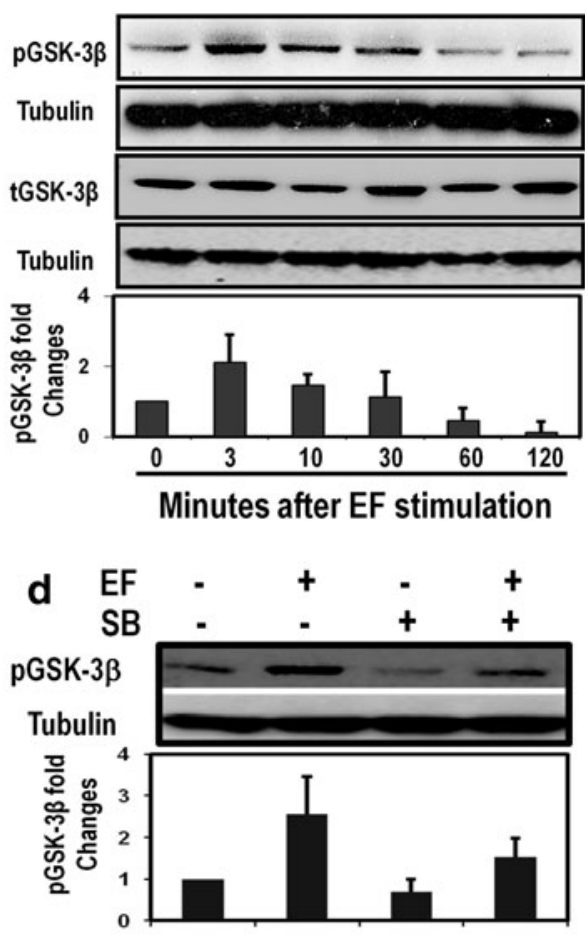

$f$
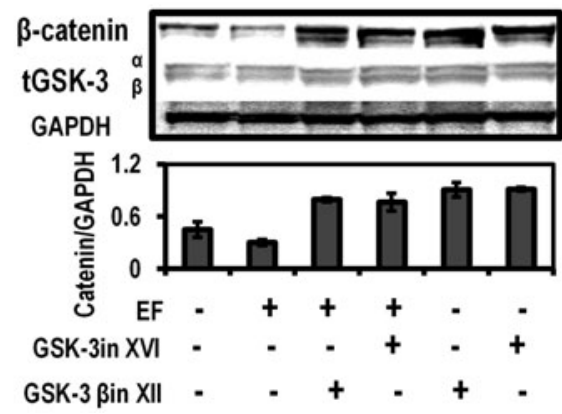
Fig. 6 GSK-3 $\beta$ was essential for EF-directed GA polarization. a, b $20 \mu \mathrm{M}$ GF109203X (PKC inhibitor) could partially reduce the EF-induced GA polarization. However, inhibitions of GSK-3 or GSK- $3 \beta$ with $20 \mu \mathrm{M}$ SB216763, $1 \mu \mathrm{M}$ GSK-3 inhibitor XVI (GSK-3in XVI) or $1 \mu \mathrm{M}$ GSK-3 $\beta$ inhibitor XII (GSK-3 $\beta$ in XII), could abolish the GA polarization induced by EF. CHO cells were pre-treated with GSK- $3 \beta$ inhibitor, $20 \mu \mathrm{M}$ SB216763, $1 \mu$ M GSK-3 inhibitor XVI (GSK-3in XVI), $1 \mu \mathrm{M}$ GSK- $3 \beta$ inhibitor XII (GSK-3 $\beta$ in XII) or $20 \mu \mathrm{M}$ GF109203X (PKC inhibitor) for $1 \mathrm{~h}$ and then subjected to $1.5-2.0 \mathrm{~V} / \mathrm{cm}$ of EFs for $3 \mathrm{~h}$. The cells were labeled with GM130 (red) and DAPI (blue). $* P<0.05$ when compared with the no field control. ${ }^{\wedge} P<0.05$ compared the field no drug control. Values are shown as mean \pm SEM. All results were from three independent experiments
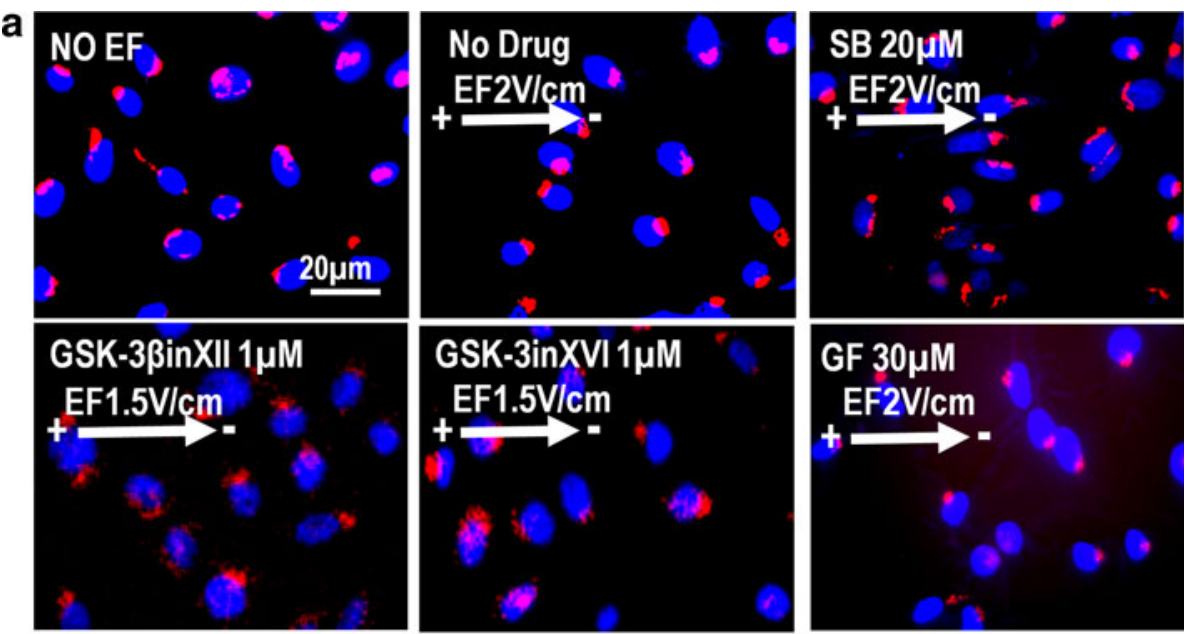

\section{b Cell with Golgi polarized to the right}

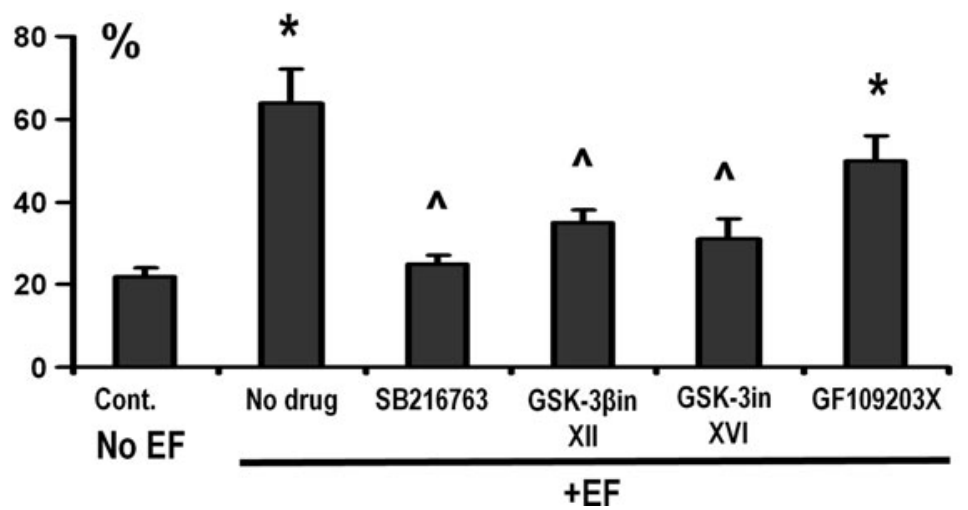

(Fig. 5c), but only partly inhibited the GA polarization (from 64 to 52\%) in an EF (Fig. 6a, b). It suggests that GA polarization induced by EF is not entirely dependent on PKC and other pathway may play an important role.

Inhibition of GSK-3 $\beta$ abolished EF-induced GA polarization

To investigate the effect of GSK-3 $\beta$ on directed migration and GA polarization, cells were pretreated for $1 \mathrm{~h}$ with SB216763 (SB, inhibitor of GSK-3 $\beta$ ), $1 \mu \mathrm{M}$ GSK-3 $\beta$ inhibitor XII and $1 \mu \mathrm{M}$ GSK-3 inhibitor XVI. The results showed that the inhibition of GSK-3 $\beta$ by SB cannot inhibit the phosphorylation of GSK-3 $\beta$ induced by EF (Fig. 5d), but it significant reduced GA polarization induced by EF (from 64 to $\sim 30 \%$ ) (Fig. 6a, b). This suggests that the GSK- $3 \beta$ is required in GA polarization induced with EF.

Inhibition of PKC or GSK-3 $\beta$ inhibited EF-induced directional cell migration

We further investigated electrotaxis when PKC or GSK-3 $\beta$ was inhibited. In cells pretreated with SB216763, GSK-3 $\beta$ inhibitor XII, GSK-3 inhibitor XVI or GF109203 (PKC inhibitor), $\sim 50 \%$ of the directedness of $\mathrm{CHO}$ cell migration in an EF was inhibited respectively $(P<0.01$, Fig $7 \mathrm{~b})$. However, the effects of inhibition of PKC and GSK-3 $\beta$ had different time courses on electrotaxis. The effect of PKC inhibition on the migration directedness happened within $1 \mathrm{~h}$ in an EF. The effect of SB (inhibition of GSK-3 $\beta$ ), on the other hand, was not significant until $3 \mathrm{~h}$ in an EF (Fig. 7a). Migration speed (Tt/T and $D x / T$ ) was significantly affected by SB216763 but not by GF109203 (Fig. 7c). These data suggest that inhibition of GSK-3 $\beta$ affect EF-induced GA polarization more significantly than electrotaxis.

\section{Discussion}

Proper cell polarization is a prerequisite for directional cell migration. We reported previously that very strong EFs $(3.0 \mathrm{~V} / \mathrm{cm})$ induce GA polarization and better electrotaxis towards the cathode in $\mathrm{CHO}$ cells caused by the parallel alignment of cell body along the EF vector [16]. CHO cells might provide an excellent system in which to investigate 
a Directedness of migration at end of 1, 2, 3 hours in an EF

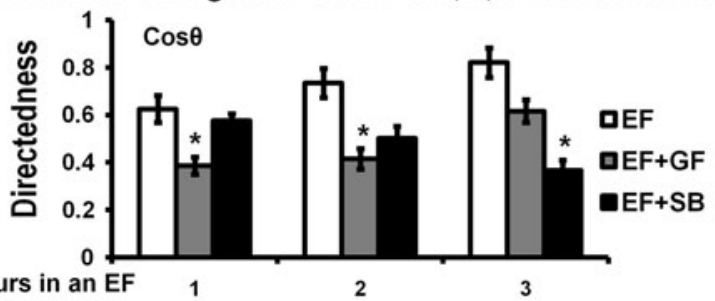

Hours in an EF 1

b Directedness of cell migration for 3 hours

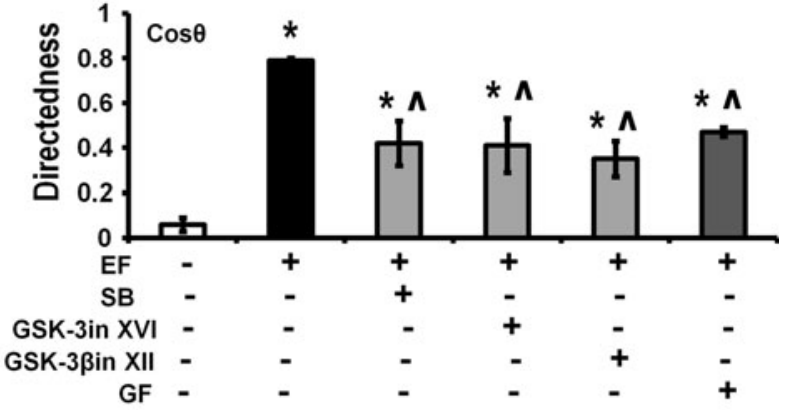

C Migration rate

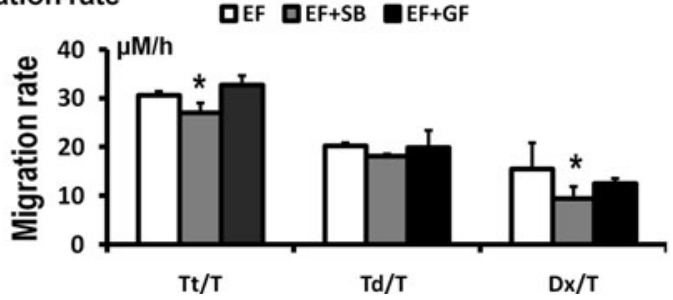

Fig. 7 GA polarization partially contributes the EF-directed cell migration. CHO cells were pre-treated with GSK-3 $\beta$ inhibitor, $20 \mu \mathrm{M}$ SB216763 (SB), $1 \mu \mathrm{M}$ GSK-3 inhibitorXVI (GSK-3in XVI), $1 \mu \mathrm{M}$ GSK-3 $\beta$ inhibitor XII (GSK-3 $\beta$ in XII) or $20 \mu \mathrm{M}$ GF109203X (GF, PKC inhibitor), and then applied to $1.5-2.0 \mathrm{~V} / \mathrm{cm}$ EF for $3 \mathrm{~h}$. a Migration directedness at the end of the first, second and third hour. The inhibitory effect of GF was significant $1 \mathrm{~h}$ in the EF, while the inhibition of SB appeared at the end of $3 \mathrm{~h}$ in an EF. $\mathbf{b}$ Inhibition of GSK-3, GSK-3 $\beta$ or PKC significantly inhibited the directedness of EF-directed migration of $\mathrm{CHO}$ cells. c The migration speed was inhibited when cell to be treated with inhibitors of GSK-3 $\beta$. But the inhibitors of PKC did not reduce the migration speed. All results were from three independent experiments. ${ }^{*} P<0.01$ compared with no EF control. ${ }^{\wedge} P<0.01$ compared with $\mathrm{EF}$ control. Values are shown as mean \pm SEM, from three independent experiments with total cell numbers of 50

microtubule-directed GA localization due to sustain a variety of their vesicular transport events [48]. In this study we show that physiological EFs induce GA polarization and directional cell migration: (1) an EF of $0.3 \mathrm{~V} / \mathrm{cm}$ that is well within the physiological range induces GA polarization and directional cell migration; (2) a physiological EF is a predominant cue directing cell's migration in the monolayer scratch wound; (3) an EF induces rapid phosphorylation (3-30 min) of GSK-3 $\beta$ and Akt; (4) EF-induced GA polarization is mediated by GSK- $3 \beta$ but not phosphorylation of GSK-3 $\beta$; and (5) EF-induced GA polarization appears to contribute to electrotaxis at a much later stage.

The physiological EFs induced GA polarization and directed migration

Physiological EFs exist in vivo and have profound influences on cell migration, cell division, cell proliferation, and nerve regeneration [17, 49-55]. We showed that a strong $\mathrm{EF}$ of $3.0 \mathrm{~V} / \mathrm{cm}$ directed GA polarization, which in turn reinforces and maintains optimal electrotaxis in $\mathrm{CHO}$ cells [16]. Our present data demonstrate that an EF as low as $0.3 \mathrm{~V} / \mathrm{cm}$ induces GA polarization and directs cell migration towards the cathode, which is the equivalent of a small voltage drop of $0.75 \mathrm{mV}$ extracellularly across a cell $25-30 \mu \mathrm{m}$ in diameter. GA polarization and directed migration by EF are voltage dependent (Figs. 1-3). The migration directedness and rate increase when the strength of the EFs increases from 0.3 to $3 \mathrm{~V} / \mathrm{cm}$. The directedness of cell migration had a similar voltage dependence and threshold as the GA polarization (Fig. 2).

GA might act as a signaling platform, integrating extracellular signal cues and thereby participating in the regulation of downstream events of directional cell migration [33]. Inhibition of traffic from the GA to plasma membrane blocks cell migration [56]. Disintegration of GA significantly inhibited cell migration [16]. EF-induced GA polarization therefore may set up a directed supply of membrane components to the front of the cells, thus facilitating and maintaining optimal directional cell migration. Our present results show that indeed the GA polarization and directional cell migration and migration rate are consistent (Figs. 1, 2). When GA polarization was abolished, the directedness of cell migration was partly reduced at the third hour after EF was applied (Figs. 6 and $7 \mathrm{a}, \mathrm{b})$. This suggests GA polarization is a facilitating and maintaining factor in directional cell migration in an EF, rather than an initial factor.

A physiological EF is a predominant cue directing cells migration

Wounding the monolayer generates unequivocal directional movement of the surrounding cells into the wound [57-62]. In this model, multiple candidate cues are generated for cell polarization and migration. These include the initial mechanical stimulation, loss of contact inhibition at the wound edge, and chemical gradients formed upon wounding [63-65]. An additional important signal may be the wound-induced EF. Endogenous EFs at the wounds in vivo are about $1.5 \mathrm{~V} / \mathrm{cm}[5]$. Our data demonstrate that EFs as low as $1 \mathrm{~V} / \mathrm{cm}$ are able to direct cell migration in a predominant manner in the monolayer wound healing 
model (Fig. 4). The responses observed at lower fields of 0.6 and $1.0 \mathrm{~V} / \mathrm{cm}$ indicate that even voltage drops as low as 1.5-2.5 $\mathrm{mV}$ per responding cell diameters are able to affect directional cell migration. An EF of $0.3 \mathrm{~V} / \mathrm{cm}$ significantly inhibited wound edge cells' migration into the wound (the directedness decreased from $\sim 0.74$ to $\sim 0.37, P<0.001$; Fig. 4). Cells at the wound edge stopped moving into the wound completely when subjected to an EF of $0.6 \mathrm{~V} / \mathrm{cm}$ applied opposite to the normal healing direction. With EFs larger than $0.6 \mathrm{~V} / \mathrm{cm}$ with the anode facing the default healing direction, $\mathrm{CHO}$ cells restored their movement but now followed the direction of electric signal regardless the direction of wound (Fig 4e, f). Therefore, a threshold for an applied EF to predominantly affect the direction of migration of wound edge cells lies between 0.6 and $1.0 \mathrm{~V} / \mathrm{cm}$. The EF-induced opening of the wound has a profound implication. Because several guidance cues collectively drive healing in this model, the complete reversal of healing must mean that an applied physiological EF has an overriding influence on the combined efforts of the other guidance cues (Fig. 4f, g). Thus, we conclude that a physiological EF is a predominant guidance cue directing cell migration in this scrape wound model.

Scratch-wounding monolayer generates reproducible and consistent cues to induce GA polarization in fibroblasts, astrocytes, and endothelial cells [25, 26, 29, 38, 39]. A physiological EF with the polarity in the healing direction induces GA to polarize directionally towards the wound (Fig 3a-e). When the EF was applied with the field vector against the normal healing direction, the field strength of $2 \mathrm{~V} / \mathrm{cm}$ was required to induce GA polarization in the field direction and away from the wound.

Chemical gradients may form at the wound site. We used cross-current flow experiments in which a continuous medium flow is maintained perpendicular to the EF vector, which would exclude chemical gradient. The result showed that fewer wound edge cells displayed GA polarization than those in non-flow EF control experiments. This indicates that chemical gradients may contribute to GA polarization.

\section{GSK- $3 \beta$ mediates EF-directed GA polarization} and migration

GSK-3 $\beta$ is a multi-task kinase that plays important roles in many signaling pathways, such as Wnt and Hedgehog signaling pathways. GSK-3 $\beta$ has been indicated in the regulation of cell division, stem cell renewal and differentiation, apoptosis, circadian rhythm, transcription, and insulin action [66-73].

Applied EFs transiently induce phosphorylation of GSK-3 $\beta$ as well as Akt (Fig. 5a, b). Applied EFs induce tyrosine phosphorylation of acetylcholine receptors, epidermal growth factor receptors (EGFR) [74, 75]. Those membrane receptors are upstream of PI3 kinase and PKC. Mitogen-activated protein kinase (MAP kinase), PI3K/Akt and PKC are upstream signaling molecules that may control phosphorylation of GSK-3 $\beta$ [76-79]. Indeed, inhibition of PI3 kinase with either LY294002 or wortmannin significantly inhibited phosphorylation of GSK-3 $\beta$ (Fig. 5e). Cross-talk amongst MAP kinase, PI3 kinase and PKC may happen, for example, PKC can be activated by PI-3,4,5(PO4)3 (PIP3), a product of PI3 kinase activation [80-83]. Our results suggest a requirement for PI3 kinase and PKC in phosphorylation of GSK-3 $\beta$, thus mediating signaling from applied EFs.

A striking role for GSK-3 $\beta$ is in the regulation of cell polarization in a monolayer wound healing model [26, 84]. In the presence of GSK-3 inhibitors (SB216763 and $\mathrm{LiCl}$ ), centrosome polarization was blocked at the wound edge. Phosphorylation of GSK-3 $\beta$, however, appears not to be essential for centrosome/GA reorientation in an astrocyte monolayer culture [26, 85].

We used three different inhibitors for GSK-3 $\beta$, SB216763, GSK-3 $\beta$ inhibitor XII and GSK-3 inhibitor XVI. All those inhibitors completely blocked EF-induced GA polarization, but did not block the phosphorylation of GSK-3 $\beta$ induced by EF (Figs. $5 d$ and 6). Inhibition of PKC with GF109203X prevented GSK-3 $\beta$ phosphorylation induced by EF, but only partially blocked the EF-induced GA polarization (Figs. 5c and 6). Those results suggest that the EF-induced GA polarization was mediated by GSK-3 $\beta$, but not through phosphorylation of GSK-3 $\beta$. When GSK$3 \beta$ was inhibited with SB216763, GSK-3 $\beta$ inhibitor XII, GSK-3 inhibitor XVI or PKC was inhibited with GF109203X, the EF-induced directedness of cell migration was reduced to $\sim 50 \%$, respectively (Fig. $7 \mathrm{~b}$ ).

In conclusion, an EF well within the physiological range $(\sim 0.3 \mathrm{~V} / \mathrm{cm})$ directs $\mathrm{GA}$ polarization and cell migration. Most importantly, GSK-3 $\beta$ and PKC are two important molecules for EF-induced establishment of cell polarization and directedness of cells migration. PKC may play a role to initiate electrotaxis, while GSK-3 $\beta$ in optimizing the electrotaxis via polarizing GA. Our data suggest that the GSK-3 $\beta$ may play an essential signaling role in physiological EF-induced GA polarization and optimal cell migration.

Acknowledgments This work is supported by NIH 1R01EY 019101. We thank the Wellcome Trust for continuous support (058551, 068012). This work was also supported in part by grants from California Institute of Regenerative Medicine RB1-01417, NSF MCB-0951199, and the Research to Prevent Blindness, Inc.

Open Access This article is distributed under the terms of the Creative Commons Attribution Noncommercial License which permits any noncommercial use, distribution, and reproduction in any medium, provided the original author(s) and source are credited. 


\section{References}

1. Jaffe LF, Vanable JW Jr (1984) Electric fields and wound healing. Clin Dermatol 2:34-44

2. McCaig CD, Zhao M (1997) Physiological electrical fields modify cell behaviour. BioEssays 19:819-826

3. McCaig CD, Rajnicek AM, Song B, Zhao M (2002) Has electrical growth cone guidance found its potential? Trends Neurosci 25:354-359

4. Nuccitelli R (2003) A role for endogenous electric fields in wound healing. Curr Top Dev Biol 58:1-26

5. Nuccitelli R (2003) Endogenous electric fields in embryos during development, regeneration and wound healing. Radiat Prot Dosimetry 106:375-383

6. Ojingwa JC, Isseroff RR (2003) Electrical stimulation of wound healing. J Invest Dermatol 121:1-12

7. Reid B, Song B, McCaig CD, Zhao M (2005) Wound healing in rat cornea: the role of electric currents. FASEB J 19:379-386

8. Reid B, Nuccitelli R, Zhao M(2007) Non-invasive measurement of bioelectric currents with a vibrating probe. Nat Protoc 2:661-669

9. Chiang MC, Cragoe EJ Jr, Vanable JW Jr (1991) Intrinsic electric fields promote epithelization of wounds in the newt, Notophthalmus viridescens. Dev Biol 146:377-385

10. Sta Iglesia DD, Vanable JW Jr (1998) Endogenous lateral electric fields around bovine corneal lesions are necessary for and can enhance normal rates of wound healing. Wound Repair Regen 6:531-542

11. Barker AT, Jaffe LF, Vanable JW Jr (1982) The glabrous epidermis of cavies contains a powerful battery. Am J Physiol 242:R358-R366

12. Chiang MJ, Robinson KR, Vanable JW Jr (1992) Electrical fields in the vicinity of epithelial wounds in the isolated bovine eye. Exp Eye Res 54:999-1003

13. Mukerjee EV, Isseroff RR, Nuccitelli R, Collins SD, Smith RL (2006) Microneedle array for measuring wound generated electric fields. Conf Proc IEEE Eng Med Biol Soc 1:4326-4328

14. Nuccitelli R, Nuccitelli P, Ramlatchan S, Sanger R, Smith PJ (2008) Imaging the electric field associated with mouse and human skin wounds. Wound Repair Regen 16:432-441

15. McCaig C, Rajnicek AM, Song B, Zhao M (2005) Controlling cell behaviour electrically: current views and future potential. Physiol Rev 85:943-978

16. Pu J, Zhao M (2005) Golgi polarization in a strong electric field. J Cell Sci 15:1117-1128

17. Robinson KR (1985) The responses of cells to electrical fields: a review. J Cell Biol 101:2023-2027

18. Sta Iglesia DD, Cragoe EJ Jr, Vanable JW Jr (1996) Electric field strength and epithelization in the newt (Notophthalmus viridescens). J Exp Zool 274:56-62

19. Zhao $M$ et al (2006) Electrical signals control wound healing through phosphatidylinositol-3-OH kinase-gamma and PTEN. Nature 442:457-460

20. Huttenlocher A, Horwitz AR (2007) Wound healing with electric potential. N Engl J Med 356:303-304

21. Zhao M (2009) Electrical fields in wound healing — an overriding signal that directs cell migration. Semin Cell Dev Biol 20:674-682

22. Vanhaesebroeck B (2006) Charging the batteries to heal wounds through PI3 K. Nat Chem Biol 2:453-455

23. Forrester JV, Lois N, Zhao M, McCaig C (2007) The spark of life: the role of electric fields in regulating cell behaviour using the eye as a model system. Ophthalmic Res 39:4-16

24. Ridley AJ, Schwartz MA, Burridge K, Firtel RA, Ginsberg MH, Borisy G, Parsons JT, Horwitz AR (2003) Cell migration: integrating signals from front to back. Science 302:1704-1709
25. Etienne-Manneville S, Hall A (2001) Integrin-mediated activation of $\mathrm{Cdc} 42$ controls cell polarity in migrating astrocytes through PKC. Cell 106:489-498

26. Etienne-Manneville S, Hall A (2003) Cdc42 regulates GSK-3beta and adenomatous polyposis coli to control cell polarity. Nature 421:753-756

27. Kupfer A, Louvard D, Singer SJ (1982) Polarization of the Golgi apparatus and the microtubule-organzing center in cultured fibroblasts at the edge of an experimental wound. Proc Natl Acad Sci USA 79:2603-2607

28. Kupfer A, Dennert G, Singer SJ (1983) Polarization of the Golgi apparatus and the microtubule-organizing center within cloned natural killer cells bound to their targets. Proc Natl Acad Sci USA 80:7224-7228

29. Nobes CD, Hall A (1999) Rho GTPases control polarity, protrusion, and adhesion during cell movement. J Cell Biol 144:1235-1244

30. Lauffenburger DA, Horwitz AF (1996) Cell migration: a physically integrated molecular process. Cell 84:359-369

31. Mitchison TJ, Cramer LP (1996) Actin-based cell motility. Cell 84:371-379

32. Mellor H (2004) Cell Moltility: Golgi signaling shapes up to ship out. Curr Biol 14:R434-R435

33. Bivona TG, Philips MR (2003) Ras pathway signaling on endomembranes. Curr Opin Cell Biol 15:136-142

34. Ferri KF, Kroemer G (2001) Organelle-specific initiation of cell death pathways. Nat Cell Biol 3:E255-E263

35. Rios RM, Bornens M (2003) The Golgi apparatus at the cell centre. Curr Opin Cell Biol 15:60-66

36. Preisinger C, Short B, De Corte V, Bruyneel E, Haas A, Kopajtich R, Gettemans J, Barr FA (2004) YSK1 is activated by the Golgi matrix protein GM130 and plays a role in cell migration through its substrate 14-3-3zeta. J Cell Biol 164:1009-1020

37. Bershadsky AD, Futerman AH (1994) Disruption of the Golgi apparatus by brefeldin A blocks cell polarization and inhibits directed cell migration. Proc Natl Acad Sci USA 91:5686-5689

38. Magdalena J, Millard TH, Etienne-Mannevelle S, Launay S, Warwick HK, Machesky LM (2003) Involvement of the Arp2/3 complex and Scar2 in Golgi polarity in scratch wound models. Mol Bio Cell 14:670-684

39. Magdalena J, Millard TH, Machesky LM (2003) Microtubule involvement in NIH 3T3 Golgi and MTOC polarity establishment. J Cell Sci 116:743-756

40. Embi N, Rylatt DB, Cohen P (1980) Glycogen synthase kinase-3 from rabbit skeletal muscle. Separation from cyclic-AMPdependent protein kinase and phosphorylase kinase. Eur J Biochem 107:519-527

41. Adrian Harwood, Braga VaniaMM (2003) Cdc42 \& GSK-3: signals at the crossroads. Nat Cell Biol 5:275-277

42. Zhao M, Agius-Fernandez A, Forrester JV, McCaig CD (1996) Orientation and directed migration of cultured corneal epithelial cells in small electric fields are serum dependent. J Cell Sci 109:1405-1414

43. Zhao M, Jin T, McCaig CD, Forrester JV, Devreotes PN (2002) Genetic analysis of the role of $\mathrm{G}$ protein-coupled receptor signaling in electrotaxis. J Cell Biol 157:921-927

44. Bai H, McCaig CD, Forrester JV, Zhao M et al (2004) DC electric fields induce distinct preangiogenic responses in microvascular and macrovascular cells. Arterioscler Thromb Vasc Biol 24:1234-1239

45. Song B, Gu Y, Pu J, Reid B, Zhao Z, Zhao M (2007) Application of direct current electric fields to cells and tissues in vitro and modulation of wound electric field in vivo. Nat Protoc 2:1479-1489 
46. He X, Saint-Jeannet JP, Woodgett JR, Varmus HE, Dawid I (1995) Glycogen synthase kinase-3 and dorsoventral patterning in Xenopus embryos. Nature 374:617-622

47. Yoshimura T, Kawano Y, Arimura N, Kawabata S, Kikuchi A, Kaibuchi K (2005) GSK-3beta regulates phosphorylation of CRMP-2 and neuronal polarity. Cell 120:137-149

48. Corthesy-Theulaz I, Pauloin A, Pfeffer SR (1992) Cytoplasmic dynein participates in the centrosomal localization of the Golgi complex. J Cell Biol 118:1333-1345

49. Song B, Zhao M, Forrester JV, McCaig CD (2002) Electrical cues regulate the orientation and frequency of cell division and the rate of wound healing in vivo. Proc Natl Acad Sci USA 99:13577-13582

50. Song B, Zhao M, Forrester JV, McCaig CD (2004) Nerve regeneration and wound healing are stimulated and directed by an endogenous electrical field in vivo. J Cell Sci 117:4681-4690

51. Wang E, Zhao M, Forrester JV, McCaig CD (2000) Re-orientation and faster, directed migration of lens epithelial cells in a physiological electric field. Exp Eye Res 71:91-98

52. Wang E, Yin Y, Zhao M, Forrester JV, McCaig CD (2003) Physiological electric fields control the G1/S phase cell cycle checkpoint to inhibit endothelial cell proliferation. FASEB J $17: 458-460$

53. Zhao M, McCaig CD, Agius-Fernandez A, Forrester JV, ArakiSasaki K (1997) Human corneal epithelial cells reorient and migrate cathodally in a small applied electric field. Curr Eye Res 16:973-984

54. Zhao M, Forrester JV, McCaig CD (1999) A small, physiological electric field orients cell division. Proc Natl Acad Sci USA 96:4942-4946

55. Zhao M, Pu J, Forrester JV, McCaig CD (2002) Membrane lipids, EGF receptors, and intracellular signals colocalize and are polarized in epithelial cells moving directionally in a physiological electric field. FASEB J 16:857-859

56. Prigozhina NL, Waterman-Storer CM (2004) Protein kinase D-mediated anterograde membrane trafficking is required for fibroblast motility. Curr Biol 14:88-98

57. Gottrup F, AM, Karlsmark T et al (2000). Models for use in wound healing research: a survey focusing on in vitro and in vivo adult soft tissue. Wound Repair Regen 8(2): 83-96

58. Jacinto A, M-A A, Martin P (2001) Mechanisms of epithelial fusion and repair. Nat Cell Biol 3:E117-123

59. Kraynov V, Chamberlain C, Bokoch GM, Schwartz MA, Slabaugh S, Hahn KM (2000) Localized Rac activation dynamics visualized in living cells. Science 290:333-337

60. Martin P (1997) Wound healing-aiming for perfect skin regeneration. Science 276:75-81

61. Nobes C, Lauritzen I, Mattei MG, Paris S, Hall A, Chardin P (1998) A new member of the Rho family, Rnd1, promotes disassembly of actin filament structures and loss of cell adhesion. J Cell Biol 141:187-197

62. Wallis S, Lloyd S, Wise I, Ireland G, Fleming TP, Garrod D (2000) The alpha isoform of protein kinase $C$ is involved in signaling the response of desmosomes to wounding in cultured epithelial cells. Mol Biol Cell 11:1077-1092

63. Grose R, Martin P (1999) Parallels between wound repair and morphogenesis in the embryo. Semin Cell Dev Biol 10:395-404

64. Martin P, Parkhurst SM (2004) Parallels between tissue repair and embryo morphogenesis. Development 131:3021-3034

65. Singer AJ, Clark RA (1999) Cutaneous wound healing. N Engl J Med 341:738-746
66. Cohen P, Frame S (2001) The renaissance of GSK3. Nat Rev Mol Cell Biol 2:769-776

67. Cross D, Culbert AA, Chalmers KA (2001) Selective smallmolecule inhibitors of glycogen synthase kinase-3 activity protect primary neurones from death. J Neurochem 77:94-102

68. Doble BW, Woodgett JR (2003) GSK-3: trickes of the trade for a multi-tasking kinase. J Cell Sci 116:1175-1186

69. Etheridge SL, SG, Heath DJ, Genever PG (2004) Expression profiling and functional analysis of wht signaling mechanisms in mesenchymal stem cells. Stem Cells 22:849-860

70. Hoeflich K, Luo J, Rubie EA, Tsao MS, Jin O, Woodgett JR (2000) Requirement for glycogen synthase kinase-3beta in cell survival and NF-kappaB activation. Nature 406:86-90

71. Klein P, Melton DA (1996) A molecular mechanism for the effect of lithium on development. Proc Natl Acad Sci USA 93:8455-8459

72. Meijer L, Flajolet M, Greengard P (2004) Pharmacological inhibitors of glycogen synthase kinase 3. Trends Pharmacol Sci 25:471-480

73. Zimmet P, Alberti KG, Shaw J (2001) Global and societal implications of the diabetes epidemic. Nature 414:782-787

74. Pu J, McCaig CD, Cao L, Zhao Z, Segall JE, Zhao M (2007) EGF receptor signalling is essential for electric-field-directed migration of breast cancer cells. J Cell Sci 120:3395-3403

75. Peng HB, Baker LP, Dai Z (1993) A role of tyrosine phosphorylation in the formation of acetylcholine receptor clusters induced by electric fields in cultured Xenopus muscle cells. J cell biol 120:197-204

76. Oudit GY, Penninger JM (2009) Cardiac regulation by phosphoinositide 3-kinases and PTEN. Cardiovasc Res 82:250-260

77. Gould TD, Zarate CA, Manji HK (2004) Glycogen synthase kinase-3: a target for novel bipolar disorder treatments. J Clin Psychiatry 65:10-21

78. Schlessinger J (1988) Signal transduction by allosteric receptor oligomerization. Trends Biochem Sci 13:443-447

79. Ullrich A, Schlessinger J (1990) Signal transduction by receptors with tyrosine kinase activity. Cell 61:203-212

80. Mendez R, Kollmorgen G, White MF, Rhoads RE (1997) Requirement of protein kinase $\mathrm{C}$ zeta for stimulation of protein synthesis by insulin. Mol Cell Biol 17:5184-5192

81. Nakanishi H, Brewer KA, Exton JH (1993) Activation of the zeta isozyme of protein kinase $\mathrm{C}$ by phosphatidylinositol 3,4,5-trisphosphate. J Biol Chem 268:13-16

82. Standaert M, Galloway L, Karnam P, Bandyopadhyay G, Moscat J, Farese RV (1997) Protein kinase C-zeta as a downstream effector of phosphatidylinositol 3-kinase during insulin stimulation in rat adipocytes. Potential role in glucose transport. J Biol Chem 272:30075-30082

83. Standaert M, Bandyopadhyay G, Perez L, Price D, Galloway L, Poklepovic A, Sajan MP, Cenni V, Sirri A, Moscat J, Toker A, Farese RV (1999) Insulin activates protein kinases C-zeta and C-lambda by an autophosphorylation-dependent mechanism and stimulates their translocation to GLUT4 vesicles and other membrane fractions in rat adipocytes. $J$ Biol Chem 274:25308-25316

84. Harwood JA (2001) Regulation of GSK-3: a cellular multiprocessor. Cell 105:821-824

85. Schlessinger K, McManus EJ, Hall A (2007) Cdc42 and noncanonical Wnt signal transduction pathways cooperate to promote cell polarity. J Cell Biol 178:355-361 